\title{
Associations between the Bovine Myostatin Gene and Milk Fatty Acid Composition in New Zealand Holstein-Friesian $\times$ Jersey-Cross Cows
}

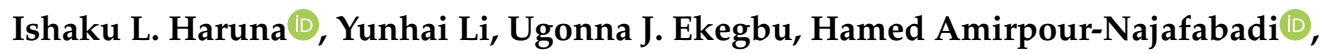 \\ Huitong Zhou and Jon G. H. Hickford *D \\ Gene-Marker Laboratory, Department of Agricultural Sciences, Faculty of Agriculture and Life Sciences, \\ Lincoln University, Lincoln 7647, New Zealand; Ishaku.Haruna@lincolnuni.ac.nz (I.L.H.); \\ Yunhai.Li@Lincolnuni.ac.nz (Y.L.); Jane.Ekegbu@lincolnuni.ac.nz (U.J.E.); \\ Hamed.Amirpour@lincolnuni.ac.nz (H.A.-N.); zhouh@lincoln.ac.nz (H.Z.) \\ * Correspondence: jon.hickford@lincoln.ac.nz; Tel.: +64-3-423-0665
}

Received: 26 May 2020; Accepted: 15 August 2020; Published: 19 August 2020

check for updates

Simple Summary: The gene that encodes myostatin influences more than one trait, and its expression has been observed in skeletal muscle, as well as the mammary gland. In this study, association analysis revealed that variation in the bovine myostatin gene affects milk fatty acid composition, raising the possibility that this genetic variation may be utilized to increase the amount of unsaturated fatty acid and decrease the amount of saturated fatty acid in milk.

\begin{abstract}
The myostatin gene (MSTN), which encodes the protein myostatin, is pleiotropic, and its expression has been associated with both increased and decreased adipogenesis and increased skeletal muscle mass in animals. In this study, the polymerase chain reaction, coupled with single strand conformation polymorphism analysis, was utilized to reveal nucleotide sequence variation in bovine MSTN in 410 New Zealand (NZ) Holstein-Friesian $\times$ Jersey $(\mathrm{HF} \times \mathrm{J})$-cross cows. These cows ranged from 3 to 9 years of age and over the time studied, produced an average $22.53 \pm 2.18 \mathrm{~L}$ of milk per day, with an average milk fat content of $4.94 \pm 0.17 \%$ and average milk protein content of $4.03 \pm 0.10 \%$. Analysis of a 406-bp amplicon from the intron 1 region, revealed five nucleotide sequence variants $(A-E)$ that contained seven nucleotide substitutions. Using general linear mixed-effect model analyses the $A D$ genotype was associated with reduced C10:0, C12:0, and C12:1 levels when compared to levels in cows with the $A A$ genotype. These associations in NZ HF $\times \mathrm{J}$ cross cows are novel, and they suggest that this variation in bovine MSTN could be explored for increasing the amount of milk unsaturated fatty acid and decreasing the amount of saturated fatty acid.
\end{abstract}

Keywords: myostatin gene; variation; milk; fatty acid; cattle

\section{Introduction}

Improving the efficiency of cattle production systems can be achieved by selecting for fast growing animals with increased muscling that have desirable maternal reproductive traits, good milk production, and good mothering ability. To achieve this, it is important to have an understanding of the genes that underpin muscularity and adiposity.

The gene for the protein myostatin (MSTN; gene MSTN), which is also called the growth and differentiation factor 8 gene (GDF8) has pleiotropic effects. Its expression has been associated with decreased adipogenesis and increased skeletal muscle mass as a result of decreased secretion of leptin [1-3]. 
Sequence variation in MSTN has been associated with increases in growth and muscling traits in several species. For example, in cattle it has been connected with having increased numbers of muscle fibers (otherwise known as "double-muscling") in a number of breeds [4]. Similarly, sequence variation in the first intron has been found to influence growth and carcass traits such as the yield of leg, loin, and total lean meat in NZ Romney sheep [5].

While there is well-documented evidence describing how variation in MSTN is associated with growth and muscle traits in beef cattle breeds, there is little information about the effects of MSTN nucleotide sequence variation on milk yield and milk fatty acid (FA) composition. There are suggestions that MSTN could affect lactation by affecting the production of fatty acid in milk, and primarily through MSTN deficiency being associated with decreased adipogenesis $[2,3,6]$.

The fat of milk from dairy cattle is approximately $70 \%$ saturated fatty acid (SFA), $25 \%$ monounsaturated fatty acid (MUFA), and 5\% polyunsaturated fatty acid (PUFA) [7]. From a human health perspective, an increase in unsaturated fatty acid (UFA) content and a decrease in SFA content could be considered favorable; and equally from a physical perspective (e.g., increased spread-ability of butter), increased relative levels of UFA would be desirable. Previously, it has been identified that the concentrations of different fatty acids in milk are affected most by four parameters: the diet of the cow [8,9], genetic variation between cows within a breed [10,11], breed differences [12,13], and the number of days in milk [14]. In their report, Strucken et al. [14] established that cows in early lactation stage are characterized by negative energy balance as the dietary energy intake is unable to meet the demands of high milk production in approximately the first 60 days of lactation. To offset this balance, an alternative energy source is needed. This leads to the mobilization of body energy stores to balance the deficit between feed intake, and energy expenditure on maintenance and milk production [15]. However, as a consequence of the cow's body fat being used up for this purpose, other biological pathways are affected, resulting in a change in milk composition. The Holstein-Friesian and the Jersey breeds have one of the most notable differences in terms of the composition of milk fatty acids. Milk from Jersey cows tend to have higher concentrations of some short- and medium-chain length SFA, but lower concentrations of some UFA [16]. These differences could be capitalized upon in order to obtain the preferred fatty acid profile through cross-breeding of these breeds.

In the above context, the objective of this research was to explore the effects of MSTN variation on key milk production traits and composition of milk fatty acids in Holstein-Friesian $\times$ Jersey $(\mathrm{HF} \times \mathrm{J})$-cross (alternatively known as Kiwicross ${ }^{\mathrm{TM}}$ ) dairy cows in Hamilton, New Zealand (NZ). This cross is now the preferred cow for dairy production in NZ and it constitutes more than half of all the dairy cows milked annually. Our working hypothesis is that variation in the gene will affect some milk traits.

\section{Materials and Methods}

\subsection{The Dairy Cattle Investigated and the Collection of Milk Samples from Them}

This research was approved by the Lincoln University Animal Ethics Committee (AEC Approval Number 521). This is a mandated and registered committee that was established, and is regularly audited, under the provisions of the New Zealand Government's Animal Welfare Act 1999 (http: //www.legislation.govt.nz/act/public/1999/0142/latest/DLM49664.html). A total of $410 \mathrm{HF} \times \mathrm{J}$-cross dairy cows (alternatively known as Kiwicross ${ }^{\mathrm{TM}}$ cows, in Hamilton, New Zealand), of individually variable and unidentified breed ratio, and of 3 to 9 years of age were investigated. The cows were managed in two herds on the Lincoln University Dairy Farm (Canterbury, New Zealand), and all of them were grazed outdoors at all times on pasture (a blend of white clover and perennial ryegrass). All of the cows calved over the months of August-September (spring in the Southern Hemisphere) and they were then milked twice a day for up to 10 months.

Milk samples for gross milk trait analysis were collected once a month from September to February and the daily milk yield in liters was recorded using Tru-test milk meters (Tru-test Ltd., Auckland, New 
Zealand) and Fourier-transform infra-red spectroscopy (MilkoScan FT 120 Foss, Hillerød, Denmark) was used to analyze milk samples for fat percentage (\%) and protein percentage (\%). Average daily milk yield, and average protein and fat percentages were calculated over the 6 months of milk collection. The milk samples for fatty acid (FA) analysis were collected at $148 \pm 19$ days in milk from each cow in a single afternoon milking in mid-January (the middle of summer in the Southern Hemisphere). These were frozen at $-20^{\circ} \mathrm{C}$, and then freeze-dried, prior to being individually ground to a fine powder for component analysis.

\subsection{Gas Chromatography of the Fatty Acids in the Milk Samples}

The FAs were methylated and extracted in n-heptane, before being analyzed by gas chromatography (GC) as FA methyl esters (FAMEs). The methylation reactions were performed in 10-mL Kimax tubes. Individual freeze-dried and powdered milk samples $(0.17 \mathrm{~g})$ were dissolved in $900 \mu \mathrm{L}$ of $\mathrm{n}$-heptane (100\%, AR grade), before $100 \mu \mathrm{L}$ of internal standard $(5 \mathrm{mg} / \mathrm{mL}$ of C21:0 methyl ester in n-heptane) and $4.0 \mathrm{~mL}$ of $0.5 \mathrm{M} \mathrm{NaOH}$ (in 100\% anhydrous methanol) were added.

The tubes were vortexed then incubated in a block heater (Ratek Instruments, Australia) at $50{ }^{\circ} \mathrm{C}$ for $15 \mathrm{~min}$. After cooling to room temperature, another $2.0 \mathrm{~mL}$ of $\mathrm{n}$-heptane and $2.0 \mathrm{~mL}$ of deionized water were added to each tube. After vortexing, the tubes were centrifuged (Megafuge 1.0R, Heraeus, Germany) for $5 \mathrm{~min}$ at $1500 \times g$. The top layer of $n$-heptane was transferred into a second Kimax tube and $2.0 \mathrm{~mL}$ of $\mathrm{n}$-heptane was added to each of the original tubes. The extraction was repeated and the n-heptane aspirates were then pooled. Anhydrous sodium sulphate $(10 \mathrm{mg})$ was added to the n-heptane extracts, to remove any residual water.

The GC analysis was carried out using a Shimadzu GC-2010 Gas Chromatograph (Shimadzu Corporation, Kyoto, Japan) equipped with a flame ionization detector and an AOC-20i auto sampler. The output was analyzed with GC Solution Software (Shimadzu). For analysis, $1 \mu \mathrm{L}$ of the n-heptane sample extract was injected into a $100 \mathrm{~m}$ GC column $(250 \mu \mathrm{m} \times 0.25 \mu \mathrm{m}$ capillary column, CP-Select, Varian) with a 1:60 split ratio. The separation was undertaken with a helium carrier gas and was run for $92 \mathrm{~min}$. The temperature of both the injector and detector were set at $250^{\circ} \mathrm{C}$ and the thermal profile of the column consisted of $45^{\circ} \mathrm{C}$ for $4 \mathrm{~min}$, followed by $27 \mathrm{~min}$ at $175^{\circ} \mathrm{C}$ (ramped at $13^{\circ} \mathrm{C} / \mathrm{min}$ ), $35 \mathrm{~min}$ at $215^{\circ} \mathrm{C}$ (ramped at $4{ }^{\circ} \mathrm{C} / \mathrm{min}$ ), and a final "bake-off" at $250{ }^{\circ} \mathrm{C}$ for $5 \mathrm{~min}$ (ramped at $25^{\circ} \mathrm{C} / \mathrm{min}$ ). The individual FAMEs were identified by the peak retention time compared to commercially obtained external standards (ME61, ME93, BR3, BR2, ME100, GLC411, and GLC463; Laroden AB, Sweden). Quantification of the individual FAMEs was based on peak area assessment and comparison with the internal and external standards. The threshold for peak area determination on the chromatogram was a 500-unit count, with peaks that were under 500-unit count, being ignored. The calculated minimum component of an individual FAME was therefore $0.01 \mathrm{~g}$ per $100 \mathrm{~g}$ of total FA.

After their individual measurement, the FAs were arranged into various groups and indices. These groups were, short-chain length FAs (SCFA) = C4:0 + C6:0 + C8:0; medium-chain length FAs $(\mathrm{MCFA})=\mathrm{C} 10: 0+\mathrm{C} 12: 0+\mathrm{C} 14: 0 ;$ long-chain length FAs $(\mathrm{LCFA})=\mathrm{C} 15: 0+\mathrm{C} 16: 0+\mathrm{C} 17: 0+\mathrm{C} 18: 0+$ $\mathrm{C} 19: 0+\mathrm{C} 20: 0+\mathrm{C} 22: 0+\mathrm{C} 24: 0 ;$ omega 3 FAs $=\mathrm{C} 18: 3$ cis-9, 12, $15+\mathrm{C} 20: 5$ cis-5,8, 11, 14, 17 + C22:5 cis-7, 10, 13, 16, 19; omega 6 FAs = C18:2 cis-9, $12+$ C18:3 cis-6, 9, $12+$ C20:3 cis-8, 11, $14+$ C20:4 cis-5, 8, 11, 14; monounsaturated FAs $($ MUFA) = C10:1 + C12:1 + C14:1 cis-9 + C15:1 + C16:1 cis-9 + C17:1 + C18:1 trans-11 + C18:1 cis-9 + C18:1 cis-(10 to 15) + C20:1 cis-5 + C20:1 cis-9 + C20:1 cis-11 + C22:1 trans-13; polyunsaturated FAs (PUFA) = C18:2 trans-9, $12+$ C18:2 cis-9,trans- $13+$ C18:2 cis-9, trans-12 + C18:2 trans-9,cis-12 + C18:2 cis-9, 12 + C18:3 cis-6, 9, 12 + C18:3 cis-9, 12, 15 + CLA + C20:3 cis-8, 11, $14+$ C20:4 cis-5, 8, 11, $14+$ C20:5 cis-5, 8, 11, 14, $17+\mathrm{C} 22: 5$ cis-7, 10, 13, 16, 19; and total branched $\mathrm{FA}=\mathrm{C} 13: 0$ iso $+\mathrm{C} 13: 0$ anteiso $+\mathrm{C} 15: 0$ iso $+\mathrm{C} 15: 0$ anteiso $+\mathrm{C} 17: 0$ iso.

Unsaturated FA indices were also calculated as follows: $\mathrm{C} 12: 1$ index (C12:1 divided by the sum of C12:0 and C12:1); $C 16: 1$ index (C16:1 cis-9 divided by the sum of $C 16: 0$ and C16:1 cis-9); and C18:1 index (C18:1 cis-9 divided by the sum of C18:0 and C18:1 cis-9). The method is as described by Li et al. [17], 
with the un-adjusted mean levels in the 430 cows being calculated and used subsequently in the statistical analyses.

\subsection{Blood Sample Collection}

Samples of blood were collected from each of the cows studied onto FTA ${ }^{\mathrm{TM}}$ cards (Whatman ${ }^{\mathrm{TM}}$, Middlesex, UK) by piercing the ear of the animal. This is allowed under a Code of Welfare issued by the NZ Minister of Agriculture, under Section 75 and 76 of the NZ Animal Welfare Act 1999. The samples were allowed to dry in the air and the purification of the DNA from 1.2-mm punches taken from the FTA $^{\mathrm{TM}}$ cards was carried out using a two-step procedure described by Zhou et al. [18].

\subsection{Polymerase Chain Reaction (PCR) Amplification of a Region of the Cattle Myostain Gene}

The intron 1 region of MSTN was amplified using forward and reverse primers (5'-catggtactattgttgagag- $3^{\prime}$ and $5^{\prime}$-aaggcaaatctattccagg- $3^{\prime}$ respectively) adapted from the work of Haruna et al. [19]. The 15- $\mu \mathrm{L}$ reactions contained the purified DNA on a 1.2-mm diameter disc of the FTA $^{\mathrm{TM}}$ card, and a content of $0.25 \mu \mathrm{M}$ for each primer, $150 \mu \mathrm{M}$ for each dNTP (Eppendorf, Hamburg, Germany), $3.0 \mathrm{mM} \mathrm{Mg}^{2+}, 0.5 \mathrm{U}$ of Taq DNA polymerase (Qiagen, Hilden, Germany), and $1 \times$ the buffer supplied with the DNA polymerase enzyme.

The PCR amplifications were carried out in Bio-Rad S1000 thermal cyclers (Bio-Rad, Hercules, CA, USA) and the thermal cycling parameters included an initial denaturation at $94{ }^{\circ} \mathrm{C}$ for $2 \mathrm{~min}$, and then 35 repeated cycles of denaturation at $94^{\circ} \mathrm{C}$ for $30 \mathrm{~s}$, primer annealing at $58^{\circ} \mathrm{C}$ for $30 \mathrm{~s}$, and primer extension at $72{ }^{\circ} \mathrm{C}$ for $30 \mathrm{~s}$. Following this process, a final extension step at $72{ }^{\circ} \mathrm{C}$ for $5 \mathrm{~min}$ was used.

\subsection{Single Strand Conformation Polymorphism (SSCP) Analysis}

An SSCP technique was employed to detect nucleotide sequence variation in the amplicons obtained from the PCR reactions. A $0.7-\mu \mathrm{L}$ aliquot of the completed reactions was added to $7 \mu \mathrm{L}$ of a solution containing $10 \mathrm{mM}$ ethylenediaminetetraacetic acid (EDTA), $0.025 \%$ bromophenol blue, $0.025 \%$ xylene-cyanol, and $98 \%$ formamide. The samples were then placed on a hot plate already set at $95{ }^{\circ} \mathrm{C}$ for $5 \mathrm{~min}$ for denaturation, followed by immediate cooling on wet ice. They were then loaded onto $14 \%$ acrylamide: bisacrylamide (37.5:1) (Bio-Rad) gels that were $16 \mathrm{~cm} \times 18 \mathrm{~cm}$ in size. Electrophoresis was undertaken using Protean II xi cells (Bio-Rad) for $19 \mathrm{~h}$ at 390 volts and $7{ }^{\circ} \mathrm{C}$ room temperature in $0.5 \times$ Tris/Borate/EDTA running buffer.

To detect the SSCP banding patterns, the SSCP gels were stained using the silver-staining method of Byun et al. [20].

\subsection{Nucleotide Sequencing and Sequence Analysis}

Based on the PCR-SSCP patterns observed nucleotide sequence variation could be identified. Cows that appeared to be homozygous with unique banding patterns were subjected to direct sequencing. For cows that appeared to have heterozygous variant patterns, unique bands were excised from the wet gel and incubated in water at $69^{\circ} \mathrm{C}$ for $1 \mathrm{~h}$. A $1-\mu \mathrm{L}$ aliquot of the water product was pipetted into $14-\mu \mathrm{L}$ of PCR pre-mixture (as used for the original PCR reactions), re-amplified using the same thermal cycle profile, and subsequently sequenced. This approach has been described in more detail by Gong et al. [21]. The sequences were aligned, and other analyses were undertaken using version 5.2.10 of DNAMAN (Lynnon BioSoft, Vaudreuil, QC, Canada).

\subsection{Statistical Analyses}

All statistical analyses were performed using IBM SPSS version 22 (IBM, Armonk, NY, USA), and an alpha level of $p<0.05$ was set as a threshold.

For genotypes with a frequency greater than $5 \%$ (thus having adequate sample size per group), the effect of variation in a cow's MSTN genotype on gross milk production traits, and the component 
levels of individual and grouped FAs was tested using general linear mixed-effects models (GLMMs) and multiple pair-wise comparisons (least significant difference tests) with Bonferroni corrections. The age of the cow expressed in an integer value of years (i.e., as a categorical variable in a range from 3 to 9 years of age), the number of days in milk for each cow (DIM; expressed as an integer value, but entered into the model as a continuous trait) and herd (to correct for herd-specific effects) were fitted to the models as fixed explanatory factors.

The model was $Y_{i j k l}=\mu+G_{i}+A_{j}+D_{k}+H_{l}+e_{i j k l}$ for genotype: where $Y_{i j k l}=$ the observed trait value in the ijklth cow; $\mu=$ the mean trait value for a given trait; $G_{i}=$ the fixed effect of ith $M S T N$ genotype; $A_{j}=$ effect of age $(j=3-9$ years $) ; D_{k}=$ effect of the number of days the cow has produced milk (DIM: $\mathrm{k}=94-186$ days); $\mathrm{H}_{1}=$ the fixed effect of 1 th farm $(1=1$ or 2$)$; and $\mathrm{e}_{\mathrm{ijkl}}=$ random error.

The effect of sire of cow could not be included in the GLMMs, because some semen straws (sire genetics) used in NZ dairy cattle artificial insemination-based breeding approaches contain mixed-sire semen purchased from commercial semen producers. In these cases, it is impossible to ascertain individual sire identity. However, since the straws were mixed-semen straws and because different sires are used for different inseminations, in different years, it is unlikely that sire was a strongly confounding effect. Cow age and herd might also be confounded with sire, but this cannot be confirmed.

\section{Results}

\subsection{Milk Production}

Over the time the cows were studied, they produced an average of $22.53 \pm 2.18 \mathrm{~L}$ of milk per day, with an average milk fat content of $4.94 \pm 0.17 \%$ and average milk protein content of $4.03 \pm 0.10 \%$.

\subsection{Identification of Nucleotide Sequence Variation in Bovine MSTN}

A $406 \mathrm{bp}$ fragment of the intron 1 region of bovine MSTN was amplified and analyzed using the polymerase chain reaction coupled with single strand conformation polymorphism (PCR-SSCP) analyses.

The PCR-SSCP analyses coupled with DNA sequencing revealed five banding patterns $(A-E)$ in the region of intron 1 investigated (Figure 1). A total of seven single-nucleotide substitutions (c.373+751G/T, c.373+803T/G, с.373+877A/G, с.373+895G/C, с.374-909C/T, с.374-842G/C, с.374-812A/G) were identified, all of which have been previously reported [19].

\subsection{MSTN Genotype Models}

The genotypes $A A(n=149), A B(n=87), A C(n=48)$ and $A D(n=63)$ occurred at a frequency over $5 \%$ and were analyzed in this model. The other genotypes $A E(n=16), B B(n=6), B C(n=5), B D$ $(n=15), C C(n=5), C D(n=7), C E(n=1)$ and $D D(n=3)$ had frequencies of less than $5 \%$ each, and were not included in the model.

In the genotype models (Table 1), genotype $A D$ was associated with a lower $\mathrm{C} 12: 0$ and $\mathrm{C} 12: 1$ levels than genotype $A A$. 
(a)

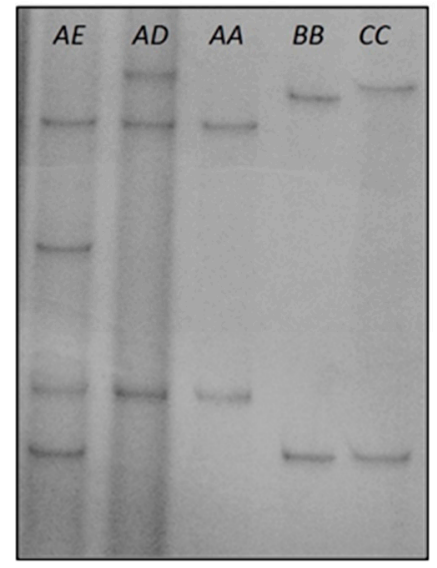

(b)

\begin{tabular}{lcccccc}
\hline \multirow{2}{*}{$\begin{array}{l}\text { Nucleotide } \\
\text { position }\end{array}$} & Nucleotide & \multicolumn{5}{c}{ Variant } \\
\cline { 3 - 7 } substitution & $A$ & $B$ & $C$ & $D$ & $E$ \\
\hline c. $373+751$ & $\mathrm{G} / \mathrm{T}$ & $\mathrm{G}$ & $\mathrm{G}$ & $\mathrm{T}$ & $\mathrm{G}$ & $\mathrm{G}$ \\
c. $373+803$ & $\mathrm{~T} / \mathrm{G}$ & $\mathrm{T}$ & $\mathrm{T}$ & $\mathrm{G}$ & $\mathrm{G}$ & $\mathrm{G}$ \\
c. $373+877$ & $\mathrm{~A} / \mathrm{G}$ & $\mathrm{A}$ & $\mathrm{A}$ & $\mathrm{G}$ & $\mathrm{G}$ & $\mathrm{A}$ \\
c. $373+895$ & $\mathrm{G} / \mathrm{C}$ & $\mathrm{G}$ & $\mathrm{G}$ & $\mathrm{C}$ & $\mathrm{G}$ & $\mathrm{G}$ \\
$\mathrm{c} .374-909$ & $\mathrm{C} / \mathrm{T}$ & $\mathrm{C}$ & $\mathrm{T}$ & $\mathrm{T}$ & $\mathrm{C}$ & $\mathrm{T}$ \\
$\mathrm{c} .374-842$ & $\mathrm{G} / \mathrm{C}$ & $\mathrm{G}$ & $\mathrm{G}$ & $\mathrm{G}$ & $\mathrm{G}$ & $\mathrm{C}$ \\
$\mathrm{c} .374-812$ & $\mathrm{~A} / \mathrm{G}$ & $\mathrm{A}$ & $\mathrm{A}$ & $\mathrm{A}$ & $\mathrm{G}$ & $\mathrm{A}$ \\
\hline
\end{tabular}

Figure 1. Variation in intron 1 of bovine MSTN revealed using PCR-SSCP analysis (a) and verified with nucleotide sequencing (b). Five PCR-SSCP patterns, representing the five distinct sequence variants ( $A-E$, in both homozygous and heterozygous genotypes) are shown.

Table 1. Associations between milk fatty acid methyl ester levels and myostatin genotypes in NZ $\mathrm{HF} \times \mathrm{J}$ cross cows $(n=347)$.

\begin{tabular}{|c|c|c|c|c|c|}
\hline \multirow{2}{*}{$\begin{array}{l}\text { Individual/Grouped } \\
\text { Fatty Acids }{ }^{1}\end{array}$} & \multicolumn{4}{|c|}{ Mean \pm Standard Error $^{2}$ (g/100 g Milk Fatty Acids) } & \multirow{2}{*}{$p^{3}$} \\
\hline & $A A(n=149)$ & $A B(n=87)$ & $A C(n=48)$ & $A D(n=63)$ & \\
\hline C4:0 & $1.264 \pm 0.012$ & $1.252 \pm 0.015$ & $1.252 \pm 0.020$ & $1.262 \pm 0.017$ & 0.871 \\
\hline C6:0 & $1.566 \pm 0.010$ & $1.548 \pm 0.013$ & $1.549 \pm 0.017$ & $1.547 \pm 0.015$ & 0.458 \\
\hline C8:0 & $1.198 \pm 0.009$ & $1.179 \pm 0.011$ & $1.188 \pm 0.014$ & $1.169 \pm 0.012$ & 0.150 \\
\hline C10:0 & $3.299 \pm 0.035$ & $3.244 \pm 0.043$ & $3.293 \pm 0.056$ & $3.164 \pm 0.050$ & 0.097 \\
\hline C10:1 & $0.294 \pm 0.004$ & $0.282 \pm 0.005$ & $0.283 \pm 0.007$ & $0.284 \pm 0.006$ & 0.108 \\
\hline C11:0 & $0.062 \pm 0.002$ & $0.058 \pm 0.002$ & $0.056 \pm 0.003$ & $0.057 \pm 0.002$ & 0.124 \\
\hline C12:0 & $4.029 \pm 0.046^{\mathrm{a}}$ & $3.939 \pm 0.057 \mathrm{ab}$ & $4.015 \pm 0.075^{\mathrm{ab}}$ & $3.824 \pm 0.067^{b}$ & 0.046 \\
\hline $\mathrm{C} 13: 0$ iso & $0.084 \pm 0.002$ & $0.079 \pm 0.002$ & $0.080 \pm 0.002$ & $0.078 \pm 0.002$ & 0.076 \\
\hline C12:1 & $0.096 \pm 0.002^{\mathrm{a}}$ & $0.091 \pm 0.002^{\mathrm{ab}}$ & $0.093 \pm 0.003^{\mathrm{ab}}$ & $0.088 \pm 0.003^{b}$ & 0.019 \\
\hline C13:0 anteiso & $0.038 \pm 0.000$ & $0.038 \pm 0.001$ & $0.038 \pm 0.001$ & $0.039 \pm 0.001$ & 0.450 \\
\hline C13:0 & $0.123 \pm 0.002$ & $0.119 \pm 0.003$ & $0.117 \pm 0.004$ & $0.118 \pm 0.004$ & 0.364 \\
\hline C14:0 & $12.513 \pm 0.079$ & $12.478 \pm 0.098$ & $12.690 \pm 0.128$ & $12.365 \pm 0.114$ & 0.266 \\
\hline C14:1 cis-9 & $1.003 \pm 0.020$ & $0.959 \pm 0.025$ & $0.967 \pm 0.033$ & $0.966 \pm 0.029$ & 0.390 \\
\hline $\mathrm{C} 15: 0$ iso & $0.296 \pm 0.002$ & $0.290 \pm 0.003$ & $0.299 \pm 0.004$ & $0.290 \pm 0.004$ & 0.148 \\
\hline
\end{tabular}


Table 1. Cont.

\begin{tabular}{|c|c|c|c|c|c|}
\hline \multirow{2}{*}{$\begin{array}{l}\text { Individual/Grouped } \\
\text { Fatty Acids } 1\end{array}$} & \multicolumn{4}{|c|}{ Mean \pm Standard Error $^{2}$ (g/100 g Milk Fatty Acids) } & \multirow{2}{*}{$p^{3}$} \\
\hline & $A A(n=149)$ & $A B(n=87)$ & $A C(n=48)$ & $A D(n=63)$ & \\
\hline C15:0 anteiso & $0.639 \pm 0.009$ & $0.633 \pm 0.011$ & $0.647 \pm 0.014$ & $0.646 \pm 0.012$ & 0.814 \\
\hline C15:0 & $1.485 \pm 0.016$ & $1.473 \pm 0.019$ & $1.474 \pm 0.026$ & $1.471 \pm 0.023$ & 0.922 \\
\hline C15:1 & $0.283 \pm 0.003$ & $0.281 \pm 0.004$ & $0.287 \pm 0.005$ & $0.286 \pm 0.004$ & 0.714 \\
\hline C16:0 & $37.396 \pm 0.288$ & $37.624 \pm 0.354$ & $36.999 \pm 0.465$ & $37.558 \pm 0.412$ & 0.711 \\
\hline C16:1 cis-9 & $1.266 \pm 0.023$ & $1.245 \pm 0.028$ & $1.273 \pm 0.037$ & $1.301 \pm 0.033$ & 0.576 \\
\hline $\mathrm{C} 17: 0$ iso & $0.555 \pm 0.006$ & $0.553 \pm 0.008$ & $0.556 \pm 0.010$ & $0.553 \pm 0.009$ & 0.987 \\
\hline $\mathrm{C} 17: 0$ & $0.690 \pm 0.006$ & $0.698 \pm 0.008$ & $0.693 \pm 0.010$ & $0.690 \pm 0.009$ & 0.816 \\
\hline $\mathrm{C} 17: 1$ & $0.195 \pm 0.002$ & $0.194 \pm 0.003$ & $0.198 \pm 0.004$ & $0.199 \pm 0.003$ & 0.639 \\
\hline C18:0 & $8.547 \pm 0.119$ & $8.652 \pm 0.146$ & $8.652 \pm 0.192$ & $8.607 \pm 0.170$ & 0.918 \\
\hline C18:1 trans-11 & $2.756 \pm 0.068$ & $2.782 \pm 0.083$ & $2.801 \pm 0.110$ & $2.794 \pm 0.097$ & 0.974 \\
\hline C18:1 cis-9 & $12.833 \pm 0.142$ & $12.891 \pm 0.175$ & $12.891 \pm 0.230$ & $13.146 \pm 0.204$ & 0.595 \\
\hline C18:2 trans $-9,12$ & $0.377 \pm 0.006$ & $0.370 \pm 0.007$ & $0.391 \pm 0.009$ & $0.381 \pm 0.008$ & 0.230 \\
\hline C18:2 cis- 9, trans -13 & $0.288 \pm 0.003$ & $0.281 \pm 0.004$ & $0.291 \pm 0.005$ & $0.292 \pm 0.005$ & 0.225 \\
\hline C18:2 cis- -9, trans -12 & $0.067 \pm 0.002$ & $0.064 \pm 0.002$ & $0.065 \pm 0.003$ & $0.067 \pm 0.002$ & 0.670 \\
\hline C18:2 trans- 9, cis-12 & $0.475 \pm 0.011$ & $0.483 \pm 0.014$ & $0.492 \pm 0.018$ & $0.473 \pm 0.016$ & 0.771 \\
\hline C18:2 cis-9,12 & $0.693 \pm 0.007$ & $0.677 \pm 0.009$ & $0.697 \pm 0.012$ & $0.699 \pm 0.011$ & 0.279 \\
\hline C19:0 & $0.140 \pm 0.003$ & $0.140 \pm 0.003$ & $0.143 \pm 0.004$ & $0.142 \pm 0.004$ & 0.890 \\
\hline C18:3 cis-6,9,12 & $0.075 \pm 0.001$ & $0.073 \pm 0.001$ & $0.074 \pm 0.002$ & $0.073 \pm 0.001$ & 0.511 \\
\hline C18:3 cis- $9,12,15$ & $0.805 \pm 0.010$ & $0.776 \pm 0.013$ & $0.818 \pm 0.017$ & $0.800 \pm 0.015$ & 0.144 \\
\hline CLA cis- 9, trans- 11 & $1.012 \pm 0.028$ & $1.001 \pm 0.034$ & $1.031 \pm 0.045$ & $1.029 \pm 0.040$ & 0.920 \\
\hline C20:0 & $0.126 \pm 0.002$ & $0.126 \pm 0.002$ & $0.130 \pm 0.003$ & $0.127 \pm 0.002$ & 0.530 \\
\hline C20:1 cis-5 & $0.060 \pm 0.001$ & $0.060 \pm 0.002$ & $0.062 \pm 0.002$ & $0.060 \pm 0.002$ & 0.891 \\
\hline C20:1 cis-9 & $0.151 \pm 0.002$ & $0.152 \pm 0.003$ & $0.149 \pm 0.004$ & $0.151 \pm 0.003$ & 0.890 \\
\hline C20:1 cis-11 & $0.077 \pm 0.001$ & $0.075 \pm 0.002$ & $0.076 \pm 0.002$ & $0.073 \pm 0.002$ & 0.093 \\
\hline C20:3 cis- $8,11,14$ & $0.030 \pm 0.001$ & $0.031 \pm 0.001$ & $0.032 \pm 0.001$ & $0.029 \pm 0.001$ & 0.137 \\
\hline C20:4 cis- $5,8,11,14$ & $0.035 \pm 0.001$ & $0.035 \pm 0.001$ & $0.034 \pm 0.001$ & $0.034 \pm 0.001$ & 0.927 \\
\hline $\mathrm{C} 22: 0$ & $0.064 \pm 0.001$ & $0.067 \pm 0.002$ & $0.066 \pm 0.002$ & $0.066 \pm 0.002$ & 0.519 \\
\hline C22:1 trans-13 & $0.066 \pm 0.001$ & $0.068 \pm 0.002$ & $0.070 \pm 0.002$ & $0.067 \pm 0.002$ & 0.190 \\
\hline C20:5 cis-5,8,11,14,17 & $0.088 \pm 0.00$ & $0.089 \pm 0.001$ & $0.089 \pm 0.002$ & $0.088 \pm 0.002$ & 0.936 \\
\hline $\mathrm{C} 24: 0$ & $0.044 \pm 0.001$ & $0.046 \pm 0.001$ & $0.044 \pm 0.001$ & $0.045 \pm 0.001$ & 0.294 \\
\hline C22:5 cis-7,10,13,16,19 & $0.123 \pm 0.002$ & $0.122 \pm 0.003$ & $0.123 \pm 0.004$ & $0.123 \pm 0.003$ & 0.996 \\
\hline SCFA & $4.030 \pm 0.027$ & $3.979 \pm 0.033$ & $3.989 \pm 0.043$ & $3.977 \pm 0.038$ & 0.451 \\
\hline MCFA & $19.841 \pm 0.148$ & $19.661 \pm 0.182$ & $19.997 \pm 0.239$ & $19.353 \pm 0.212$ & 0.127 \\
\hline LCFA & $48.492 \pm 0.252$ & $48.826 \pm 0.310$ & $48.201 \pm 0.407$ & $48.706 \pm 0.360$ & 0.587 \\
\hline Total C18:1 & $16.300 \pm 0.168$ & $16.383 \pm 0.206$ & $16.400 \pm 0.271$ & $16.654 \pm 0.240$ & 0.634 \\
\hline Total C18:2 & $2.911 \pm 0.041$ & $2.876 \pm 0.051$ & $2.969 \pm 0.067$ & $2.940 \pm 0.059$ & 0.664 \\
\hline Total C18:3 & $0.880 \pm 0.011$ & $0.849 \pm 0.013$ & $0.893 \pm 0.017$ & $0.873 \pm 0.015$ & 0.123 \\
\hline Omega 3 & $1.017 \pm 0.011$ & $0.987 \pm 0.014$ & $1.030 \pm 0.018$ & $1.011 \pm 0.016$ & 0.173 \\
\hline Omega 6 & $0.832 \pm 0.008$ & $0.815 \pm 0.010$ & $0.838 \pm 0.013$ & $0.836 \pm 0.011$ & 0.317 \\
\hline MUFA & $19.792 \pm 0.174$ & $19.790 \pm 0.214$ & $19.858 \pm 0.281$ & $20.128 \pm 0.249$ & 0.657 \\
\hline PUFA & $4.067 \pm 0.044$ & $4.002 \pm 0.054$ & $4.139 \pm 0.071$ & $4.088 \pm 0.063$ & 0.410 \\
\hline Branched FA & $1.611 \pm 0.014$ & $1.593 \pm 0.017$ & $1.620 \pm 0.022$ & $1.605 \pm 0.020$ & 0.735 \\
\hline Total UFA & $23.859 \pm 0.206$ & $23.792 \pm 0.254$ & $23.997 \pm 0.334$ & $24.216 \pm 0.295$ & 0.663 \\
\hline Total SFA & $72.548 \pm 0.225$ & $72.643 \pm 0.277$ & $72.362 \pm 0.364$ & $72.210 \pm 0.323$ & 0.701 \\
\hline Unsaturated index & $24.756 \pm 0.218$ & $24.678 \pm 0.269$ & $24.911 \pm 0.353$ & $25.119 \pm 0.313$ & 0.677 \\
\hline C10:1 index & $8.252 \pm 0.136$ & $8.032 \pm 0.167$ & $7.972 \pm 0.219$ & $8.321 \pm 0.194$ & 0.410 \\
\hline C12:1 index & $2.328 \pm 0.034$ & $2.239 \pm 0.042$ & $2.266 \pm 0.055$ & $2.256 \pm 0.048$ & 0.243 \\
\hline C14:1 index & $7.424 \pm 0.148$ & $7.133 \pm 0.183$ & $7.087 \pm 0.240$ & $7.256 \pm 0.213$ & 0.427 \\
\hline C16:1 index & $3.281 \pm 0.052$ & $3.200 \pm 0.063$ & $3.319 \pm 0.083$ & $3.338 \pm 0.074$ & 0.435 \\
\hline C18:1 index & $65.594 \pm 0.331$ & $65.409 \pm 0.407$ & $65.514 \pm 0.535$ & $65.913 \pm 0.474$ & 0.855 \\
\hline CLA index & $26.626 \pm 0.269$ & $26.339 \pm 0.332$ & $26.725 \pm 0.436$ & $26.868 \pm 0.386$ & 0.716 \\
\hline
\end{tabular}

${ }^{1}$ SCFA- short-chain length fatty acid; MCFA - medium-chain length fatty acid; LCFA-long-chain length fatty acid; MUFA - monounsaturated fatty acid; PUFA - polyunsaturated fatty acid; UFA— unsaturated fatty acid; SFA - saturated fatty acid. ${ }^{2}$ Predicted means and standard error of those means derived from general linear mixed-effects models (GLMM). Myostatin genotype (categorical variable), cow age (categorical), herd (categorical), and days in milk (continuous) were fitted to the model as fixed effects. Means within a row that do not share a superscript letter are separated at $p<0.05 .{ }^{3} 0.05<p<0.2$ in italics, while $p<0.05$ in bold. 


\section{Discussion}

This is the first study demonstrating association of MSTN sequence variants with the component levels of two milk FAs in NZ HF $\times$ J cross cattle.

All seven of the nucleotide substitutions identified in this study have been previously reported in a study of NZ cattle breeds, which included; Hereford, Angus, Shorthorn, Charolais, Red Poll, South Devon, Simmental, Murray Grey, HF $\times$ J cross cattle, and some composite breeds [19]. The nucleotide substitutions c.373+751G/T, c.373+803T/G, c.373+877A/G, c.373+895G/C, and c.374-909C/T were identified in all the ten aforementioned breeds, while c.374-842G/C was found in all but four breeds (Red Poll, Shorthorn, Simmental, and Composites breeds) and the c.374-812A/G was only found in Shorthorn and $\mathrm{HF} \times \mathrm{J}$ cross breeds.

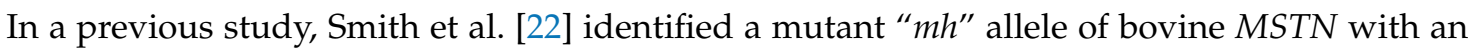
11-bp deletion in the exon 3 region. This was described in British South Devon cattle, and it was the same allele first identified in the Belgian Blue breed, causing the "double-muscled" phenotype. Also, in a later investigation of MSTN in 146 British South Devon cattle, Wiener et al. [23] showed that this

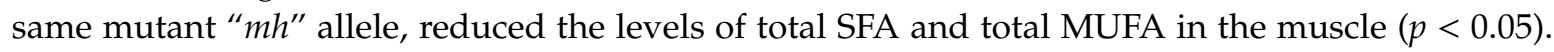
Their report also revealed an increase in the ratio of PUFA: SFA in total lipid to be greater in $\mathrm{mh} / \mathrm{mh}$ individuals than in the other two genotype $(m h /+$ and $+/+)$ classes $(p<0.001)$. This suggested that the " $m h$ " allele is associated with reduced fat levels, particularly with the levels of SFA and MUFA. The increase in the ratio of PUFA to SFA would be expected, especially when the concentration of muscle fat decreases.

In a similar report on associations between the " $m h$ " allele carrying the 11-bp deletion with intramuscular fatty acid composition in MSTN of Belgian Blue young bulls, Raes et al. [24] revealed that animals with the +/+ (normal) genotype showed a higher relative amount of the SFA; C14:0 and C16:0 and a higher relative amount of all MUFA C16:1; C17:1 and C18:1, but the relative proportion

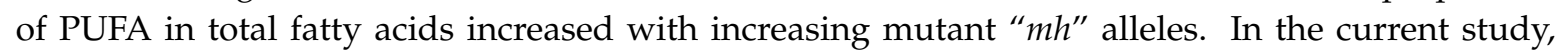
the genotype model revealed that cows carrying the $A A$ genotype showed an increase in the amount of two medium-chain length SFAs (C12:0 and C12:1) relative to $A D$ cows. While it may be difficult to conclude that the findings in the current study are similar to the work of Weiner et al. [23] and Raes et al. [24], especially because it investigated the intronic region of MSTN in non-doubled muscled cattle breed, it is important to note that variations in the intronic regions are equally capable of influencing gene expression and/or altering the functionality of a gene [25]. In a previous investigation, He et al. [25] transformed C2C12 cell-lines with a transgene construct that contained bovine MSTN promoter (pMD-MSTNPro) and a second construct that contained the first intron of bovine MSTN (pMD-Intron1). They observed an increase in the mean fluorescence intensity of green fluorescent protein (GFP) gene and the percentage of fluorescence positive cells, and concluded from this that the presence of intron 1 of bovine MSTN increased the expression of GFP in the transformed cells.

The findings in this study are in part in agreement with the findings of Buske et al. [26]. That study revealed that one copy of the so-called "wild-type + allele" of MSTN was associated with higher milk, protein, and fat yields in dual purpose Belgian Blue (DP-BB) cows, whereas a single copy of the mutant " $m h^{\prime}$ " allele (associated with double muscling) was associated with a decrease in the SFA content of

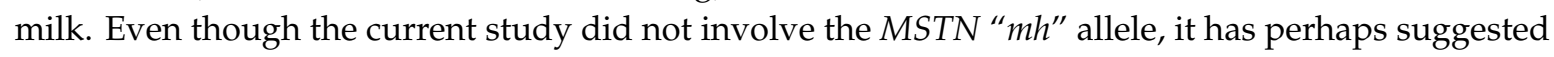
that antagonistic effects may exist between milk and meat production traits in the context of MSTN.

Since the MSTN variations in the current study occurred in a non-expressed region of the gene, it is perhaps less obvious how they might affect the structure or function of the MSTN protein. They might however influence the rate of transcription and/or translation of the gene, as was described by Liu et al. [27] in an investigation that involved both transgenic mice and in vitro studies. In that study, intron sequences in the transgene that encoded rat growth hormone were observed to stimulate transcription by promoting assembly of an ordered nucleosome array in the vicinity of the promoter. Additionally, while the observed intron variation does not yield any amino acid change, several studies have shown that synonymous nucleotide substitutions can affect the phenotypic characteristics of the 
protein product by altering mRNA structure, protein stability, the electrical charge of the resulting polypeptide, and codon usage during mRNA translation [28,29].

Previous reports on the differences in the composition of milk FAs between Holstein-Friesian and the Jersey breeds suggest that milk from Jersey cows tends to have higher concentrations of some shortand medium-chain length SFA, but lower concentrations of some UFA [16]. It is therefore interesting to note that the current investigation of $\mathrm{NZ} \mathrm{HF} \times \mathrm{J}$ cross cows, revealed that variant $D$ was associated with a decrease in the amount of two medium-chain length SFAs in milk. This discovery could be of benefit in terms of its potential applicability in cross-breeding and gene-marker development, particularly in selection for decreased SFA in milk.

\section{Conclusions}

The findings suggest that variation in MSTN affects two milk FA traits and this may be of value in breeding dairy cattle. Notably, variant $D$ of MSTN is associated with a decrease in two medium-chain length SFA levels. Cows with the $A D$ genotype might therefore produce a "preferred" FA profile in milk. However, because there were insufficient cattle with the homozygous genotypes $B B, C C$, and $D D$, or the heterozygous genotypes $(B C, B D, C E$, and $C D)$ in the samples investigated, further investigation involving much larger sample sizes across different farms and breeds of cattle is needed to validate this claim.

Author Contributions: Conceptualization, J.G.H.H. and H.Z.; methodology, I.L.H., U.J.E., and H.A.-N.; software, Y.L., and H.A.-N.; validation, J.G.H.H., and H.Z.; formal analysis, Y.L., H.A.-N.; investigation, I.L.H. and U.J.E.; resources, J.G.H.H. and H.Z.; data curation, H.Z.; writing—original draft preparation, I.L.H.; writing一review and editing, I.L.H., J.G.H.H., and H.Z.; visualization, H.Z.; supervision, J.G.H.H.; project administration, J.G.H.H. All authors have read and agreed to the published version of the manuscript.

Funding: This research received no external funding.

Acknowledgments: The authors would like to thank Freeman Fang for technical support.

Conflicts of Interest: The authors declare no conflict of interest.

\section{References}

1. McPherron, A.C.; Lawler, A.M.; Lee, S.J. Regulation of skeletal muscle mass in mice by a new TGF-b superfamily member. Nature 1997, 387, 83-90. [CrossRef] [PubMed]

2. Mendias, C.L.; Bakhurin, K.I.; Faulkner, J.A. Tendons of myostatin-deficient mice are small, brittle, and hypocellular. Proc. Natl. Acad. Sci. USA 2008, 105, 388-393. [CrossRef] [PubMed]

3. Whittemore, L.A.; Song, K.; Li, X.; Aghajanian, J.; Davies, M.; Girgenrath, S.; Hill, J.J.; Jalenak, M.; Kelley, P.; Knight, A.; et al. Inhibition of myostatin in adult mice increases skeletal muscle mass and strength. Biochem. Biophys. Res. Commun. 2003, 300, 965-971. [CrossRef]

4. Kambadur, R.; Sharma, M.; Smith, T.P.; Bass, J.J. Mutations in myostatin (GDF8) in double-muscled Belgian Blue and Piedmontese cattle. Genome Res. 1997, 7, 910-916. [CrossRef]

5. Hickford, J.G.H.; Forrest, R.H.; Zhou, H.; Fang, Q.; Han, J.; Frampton, C.M.; Horrell, A.L. Polymorphisms in the ovine myostatin gene (MSTN) and their association with growth and carcass traits in New Zealand Romney sheep. Anim. Genet. 2010, 41, 64-72. [CrossRef]

6. McPherron, A.C.; Lee, S.J. Suppression of body fat accumulation in myostatin-deficient mice. J. Clin. Investig. 2002, 109, 595-601. [CrossRef]

7. Grummer, R.R. Effects of feed on the composition of milk fat. J. Dairy Sci. 1991, 74, 3244-3257. [CrossRef]

8. Palmquist, D.L.; Beaulieu, A.D.; Barbano, D.M. Feed and animal factors influencing milk fat composition. J. Dairy Sci. 1993, 76, 1753-1771. [CrossRef]

9. Dewhurst, R.J.; Shingfield, K.J.; Lee, M.R.F.; Scollan, N.D. Increasing the concentrations of beneficial polyunsaturated fatty acids in milk produced by dairy cows in high-forage systems. Anim. Feed Sci. Technol. 2006, 131, 168-206. [CrossRef] 
10. Soyeurt, H.; Dardenne, P.F.; Dehareng, G.; Lognay, G.; Veselko, D.; Marlier, M.; Bertozzi, C.; Mayeres, P.; Gengler, N. Estimating fatty acid content in cow milk using mid-infrared spectrometry. J. Dairy Sci. 2006, 89, 3690-3695. [CrossRef]

11. Stoop, W.M.; van Arendonk, J.A.M.; Heck, J.M.L.; van Valenberg, H.J.F.; Bovenhuis, H. Genetic parameters for major milk fatty acids and milk production traits of Dutch Holstein Friesians. J. Dairy Sci. 2008, 91, 385-394. [CrossRef] [PubMed]

12. Palladino, R.A.; Buckley, F.; Prendiville, R.; Murphy, J.J.; Callan, J.; Kenny, D.A. A comparison between Holstein-Friesian and Jersey dairy cows and their $\mathrm{f} 1$ hybrid on milk fatty acid composition under grazing conditions. J. Dairy Sci. 2010, 93, 2176-2184. [CrossRef] [PubMed]

13. Maurice-Van Eijndhoven, M.H.T.; Hiemstra, S.J.; Calus, M.P.L. Short communication: Milk fat composition of 4 cattle breeds in the Netherlands. J. Dairy Sci. 2011, 94, 1021-1025. [CrossRef] [PubMed]

14. Strucken, E.M.; Laurenson, Y.C.S.M.; Brockmann, G.A. Go with the flow-biology and genetics of the lactation cycle. Front. Genet. 2015, 6, 118. [CrossRef] [PubMed]

15. Bauman, D.E.; Bruce Currie, W. Partitioning of nutrients during pregnancy and lactation: A review of mechanisms involving homeostasis and homeorhesis. J. Dairy Sci. 1980, 63, 1514-1529. [CrossRef]

16. Arnould, V.M.R.; Soyeurt, H. Genetic variability of milk fatty acids. J. Appl. Genet. 2009, 209, 29-39. [CrossRef]

17. Li, Y.; Zhou, H.; Cheng, L.; Edwards, G.R.; Hickford, G.H.J. Effect of DGAT1 variant (K232A) on milk traits and milk fat composition in outdoor pasture-grazed dairy cattle. NZ. J. Agric. Res. 2019. [CrossRef]

18. Zhou, H.; Hickford, G.H.J.; Fang, Q. A two-step procedure for extracting genomic DNA from dried blood spots on filter paper for polymerase chain reaction amplification. Anal. Biochem. 2006, 354, 159-161. [CrossRef]

19. Haruna, I.L.; Ekegbu, U.J.; Ullah, F.; Amirpour-Najafabadi, H.; Zhou, H.; Hickford, J.G.H. Genetic variation and haplotypic diversity in the myostatin gene of New Zealand cattle breeds. Gene 2020, 740. [CrossRef]

20. Byun, S.O.; Fang, Q.; Zhou, H.; Hickford, J.G.H. An effective method for silver-staining DNA in large numbers of polyacrylamide gels. Anal. Biochem. 2009, 385, 174-175. [CrossRef]

21. Gong, H.; Zhou, H.; Hickford, J.G.H. Diversity of the glycine/tyrosine-rich keratin-associated protein 6 gene (KAP6) family in sheep. Mol. Biol. Rep. 2011, 38, 31-35. [CrossRef] [PubMed]

22. Smith, J.A.; Lewis, A.M.; Wiener, P.; Williams, J.L. Genetic variation in the bovine myostatin gene in UK beef cattle: Allele frequencies and haplotype analysis in the South Devon. Anim. Genet. 2000, 31, 306-309. [CrossRef] [PubMed]

23. Wiener, P.; Woolliams, J.A.; Frank-Lawale, A.; Ryan, M.; Richardson, R.I.; Nute, G.R.; Wood, J.D.; Homer, D.; Williams, J.L. The effects of a mutation in the myostatin gene on meat and carcass quality. Meat Sci. 2009, 83, 127-134. [CrossRef] [PubMed]

24. Raes, K.; de Smet, S.; Demeyer, D. Effect of double muscling in Belgian Blue young bulls on the intramuscular fatty acid composition with emphasis on conjugated linoleic acid and polyunsaturated fatty acids. Anim. Sci. 2001, 73, 253-260. [CrossRef]

25. He, Y.L.; Wu, Y.H.; Quan, F.S.; Liu, Y.G.; Zhang, Y. Molecular analysis of the first intron in the bovine myostatin gene. Mol. Biol. Rep. 2010, 38, 4643-4649. [CrossRef]

26. Buske, B.; Gengler, N.; Soyeurt, H. Short-communication: Influence of the muscle hypertrophy mutation of the myostatin gene on milk production traits and milk fatty acid composition in dual-purpose Belgian Blue dairy cattle. J. Dairy Sci. 2011, 94, 3687-3692. [CrossRef]

27. Liu, K.; Sandgren, E.P.; Palmiter, R.D.; Stein, A. Rat growth hormone gene introns stimulate nucleosome alignment in vitro and in transgenic mice. Proc. Natl. Acad. Sci. USA 1995, 92, 7724-7728. [CrossRef]

28. Sauna, Z.E.; Kimchi-Sarfaty, C. Understanding the contribution of synonymous mutations to human disease. Nat. Rev. Genet. 2011, 12, 683-691. [CrossRef]

29. Hunt, R.C.; Simhadri, V.L.; Iandoli, M.; Sauna, Z.E.; Kimchi-Sarfaty, C. Exposing synonymous mutations. Trends Genet. 2014, 30, 308-321. [CrossRef]

(C) 2020 by the authors. Licensee MDPI, Basel, Switzerland. This article is an open access article distributed under the terms and conditions of the Creative Commons Attribution (CC BY) license (http://creativecommons.org/licenses/by/4.0/). 